\title{
The Geotechnical Properties Of Clay Occurrences Around Kutigi Central Bida Basin, Nigeria.
}

1Akhirevbulu O.E. and ${ }^{2}$ Ogunbajo M.I

doi: $10.4314 /$ ejesm.v4i1.3

\begin{abstract}
The aim of this research project is to investigate occurrences of clay around Kutigi with an objective to determine its geotechnical properties. The study area (Kutigi) falls within the Bida Basin of Niger State. The methodology of research includes detailed mapping of the area, collection of clay samples, determination of; natural moisture contents, Atterberg limit, plasticity index, sieve analysis and coefficients of permeability. The results of the geotechnical analysis of the clay samples, suggests an average; moisture content of about $0.9 \%$ and $0.72 \%$, liquid limit of about $19.9 \%$ and $22.1 \%$, plastic limit of about $14.1 \%$ and $16.8 \%$, plasticity index of about 5.8 and $5.3 \%$, and a linear shrinkage limit of about $7.2 \%$ and $5.9 \%$, for both locations $A$ and $B$ respectively. Results of the plasticity classification chart suggest that the soils are composed of inorganic clay of low plasticity. While results from the modified plasticity classification chart revealed three clay minerals; these include montmorillonite (35\%), illite (35\%) and kaolinite (30\%). A simple comparison of sieve analysis results suggest soils from location A to be more coarse-grained within the coarser half of the sieves (i.e. between $5 \mathrm{~mm}$ to $0.3 \mathrm{~mm}$ ), and also more finegrained in the finer half of the sieves (i.e. between $0.01 \mathrm{~mm}$ to $0.075 \mathrm{~mm}$ ) than soils from location $B$. The grain-size curves were classified as those of immature residual soil. Their analyses suggest the texture of the soil to be predominantly sandy. Results of the estimated coefficient of permeability, classified about $25 \%$ of the soils as coarse sand and about $75 \%$ of the soils as fine sand. These suggest the soils to be predominantly sandy and highly permeable. The results of the geotechnical investigation of the Kutigi clay deposits and an earlier mineralogical and geochemical analysis suggest that the clay can be utilized in the manufacturing of ceramics, refractory bricks, paper, fertilizer and paint.
\end{abstract}

\section{Introduction}

lay and clay minerals have been
mined since the Stone Age and has been indispensable in architecture, in industry, and agriculture. Today they are among the most important minerals used by manufacturing and environmental studies. Clay has a wide spread occurrence in the world. In Nigeria, clay is widely distributed though not always found in sufficient quantity or suitable quality for modern industrial purposes. It occurs both as residual and sedimentary clay. More than 80 clay deposits have been reported from all parts of the country. Clay deposits occur in Abak, Akwa Ibom State, Uruove near Ughelli in Delta State, Ifon in Ondo State, Mokola in Oyo State, Sokoto in Sokoto State, Gombe in Gombe State, Dangara in Niger State, Umuahia in Abia State, Onitsha in Anambra State e.t.c.

Almost every State in Nigeria has at least one known deposit of kaolin. In Anambra State there is the Ozubulu deposit, Darazo kaolin deposit in Bauchi, Akpene-Obom deposit in Cross River State, Kankara in Kaduna State e.t.c. The three most extensively studied deposits are the Ozubulu kaolin deposits, Kankara deposits and the Major Porter deposits, in Plateau State. The focus of this work is to investigate clay occurrences around Kutigi as well as to determine its geotechnical properties.

Study Location.
The study area (Kutigi) is situated in Lavun Local Government Area of Niger State, within Bida basin (one of the sedimentary basins in Nigeria). It lies between longitude $5^{\circ}$ $35^{1} \mathrm{E}$ and $5^{\circ} 39^{1} \mathrm{E}$ and latitude $9^{\circ} 10^{1} \mathrm{~N}$ and $9^{\circ}$ $13^{1} \mathrm{~N}$ of Nigeria on sheet 183 Egbako S.W (Fig. 1.). It covers an area of about $39.88 \mathrm{~km}^{2}$. Kutigi is the major town in the area, while the surrounding villages include Kusogi, Shebe, Makufu, Fazhi and Ruga. The physical landform of Kutigi area is made up of flat-lying to gently rolling plains. The monotony of the landscape is however broken by residual hills, which are either conical or flat-topped. The area is mark by a NW-SE and a NE-SE running ridges that are prominently composed of laterite. The ridges ranges from $15 \mathrm{~m}$ to $50 \mathrm{~m}$ in height as observed along the road cutting between Kutigi town and Ruga village.The terrain is mostly covered by laterite and fairly by soil and sandstone as a result of the weathering activities that have depleted the hills and ridges. The area is particularly drained by river Toro which run near Kusogi village and flow in the NE direction of Egbako SW. Many insequent streams that enters river Toro as tributaries are seasonal and forms a dentritic drainage pattern which strongly suggest that the terrain is composed of lithological, structural and topographic homogeneity basement, which created fault patterns trending northeast-

${ }_{1}^{1}$ Department of Physics, Ambrose Alli University Ekpoma, Edo State, Nigeria. ojeabu@yahoo.com

2 Department of Geology, Federal University of Technology Minna, Niger State, Nigeria 
southwest and northwest-southeast (Kogbe, 1981). A rift origin for the basin has been postulated by Kogbe (1981) whilst Whiteman (1982) suggested the basin to have been formed from simple cratonic sag. The sedimentation data presented suggest that the central Bida basin was formed by rifting or by cratonic sagging.

\section{Literature Review}

Adeleye (1971), and Adeleye and Dessauvagie (1972) identified clays in the Middle Niger Basin or the Nupe sandstone now renamed the Nupe Group. They studied the Stratigraphic succession in the area and reported the direct overlying of the basement complex by a coarse conglomerate, claysandstone admixture, boulders etc of sedimentary origin. These, according to Adeleye, were themselves overlain by sandstone, and subsidiary claystones, conglomerate and siltstones. The University of Ife (Adegoke, 1979) and Ahmadu Bello University Consultancy team also studied clays in parts of Bida basin. Adegoke, (1979) worked on the structural properties of these clays at temperatures of $600^{\circ} \mathrm{C}-1000{ }^{\circ} \mathrm{C}$. All the clay occurrences investigated fall within the Cretaceous Maestrichtian in middle Niger basin (Bida Basin). The two main types of clays in the area are the earthy brownish to red lateritic clays and the grayish ball clays. There are also the whitish and silty kaolinites. The lateritic clay occurs beneath thin to thick covers of laterite on residual hills. The earthy lateritic clays are ubiquitous in occurrence. The grayish ball-clays within the Bida basin occur on alluvial plains of rivers. These are seemingly secondarily derived clays deposited from suspension load in the streams. They are generally plastic in nature. There are other similar clays but those are derived from the feldspar rich basement rocks (Adegoke, 1979).

Sedimentary kaolin deposit are known to occur in Nigeria mainly as beds, lenses or bands within the Cretaceous and Tertiary sedimentary sequences in the Sokoto, Benue, Chad and particularly the Niger Delta Basins. Prominent sedimentary kaolin deposits reported from some of these basins include among others, those at Nsu, Ifon, Enugu, Ozubulu, Oza-Nagogo, Ubiaja, Sapele and Warri (Waudby- Smith, (1957); Proceng Consultants report, (1974); Faseke, (1981); Aderibigbe and Chukwuogo (1984); Coker (1986); Enu and Adegoke, (1986) and Emofurieta, (1988).
Alabi, (2005) identified two clay deposits in Kutigi. The clay deposits he said were of varying thickness, capped by thin layer of lateritic soil and vary from white to dirty white in colour due to stains from the over burden laterite.

The first hill visited (which he called location A) is located behind ministry of works north east of Kutigi town. The second hill visited (which he called location B) is located behind Sharia Court, north west of Kutigi town. He explored and estimated the reserve extent of the clay deposits. Geophysical evidence of Alabi, (2005) suggests that the total reserve of the Kutigi clay deposits is estimated to about 672,579 tons, with an aerial extent of about 57, $400 \mathrm{~m}^{2}$ of clay bed in location A, and also an area extent of $300 \mathrm{~m}^{2}$ in location $B$. The results of his physical analysis show medium plasticity index average of $30 \%$, Specific gravity of 2.61 and medium linear shrinkage average of $2.68 \%$. His chemical analysis show the high dominance of $\mathrm{SiO}_{2} 66 \%, \mathrm{Al}_{2} \mathrm{O}_{3} 26.87 \%, \mathrm{TiO}_{2} 1.45 \%, \mathrm{Fe}_{2} \mathrm{O}_{3}$ $0.99 \%$, while the remaining $4.69 \%$ represents other elements in trace amount.

Average mineralogical composition of analyzed clay samples show the dominance of kaolinite $85 \%$, quartz $13 \%$ and $\mathrm{K}$ - feldspar as trace. He observed that Kutigi kaolin was found to be similar to the Oza-Nagogo kaolin by simple comparison with some well known kaolin deposits. From various tests conducted on Kutigi clay, he reported that Kutigi clay occur as residual clay due to the weathering of feldspar from feldspathic sandstone and its high quartz content. The clay, which is predominantly kaolinitic from its mineralogical composition, was noted to be suitable as raw material to the ceramic, paper, refractory and paint industries respectively.

\section{Research Methodology}

Detailed field mapping was carried out around Kutigi in order to establish the local geology of the area. The method of investigation involved an intensive fieldwork, which lasted for eight days. For the purpose of this study, a map extract was adopted from a topographical map on sheet 183 of Egbako SW of Niger State at a scale of 1: 50,000. The map extract, which now constitute the base map of the study area, was enlarged to a scale size of 1 : 12,500 . It covers an area of about $39.88 \mathrm{~km}^{2}$. The area was divided into four equal squares to ensure thorough mapping. 
(a)

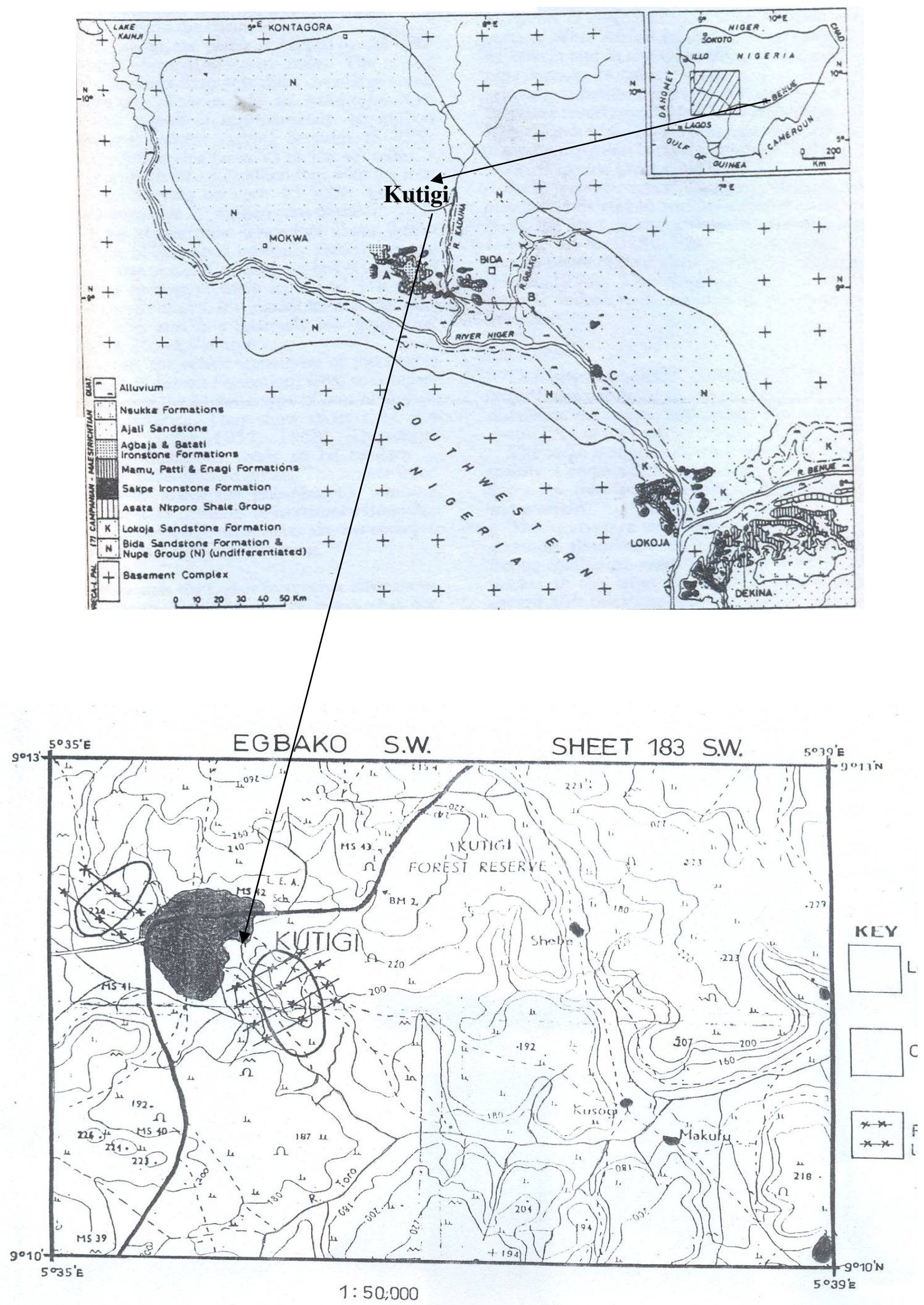

Fig. 1: LOCATION MAP OF KUTIGI AREA WITHIN NIGERIA AND BIDA BASIN

(a) Within the Bida Basin of Nigeria (after, Adeleye, 1971)

(b) Within Topographic Sheet 183 SWY 
On the field, the soil exposures were observed and described based on their grain sizes, colour, texture, structural elements and mode of occurrence. To actualize the set goal, a clinometer was used to measure the direction of trend of the exposure; a geological hammer for sample collection; markers to mark off points on the base map where soil samples were collected; a measuring tape to measure distances; masking tape for sample labeling; neat polythene bags to store or temporarily preserve collected soil samples for laboratory analysis, a field notebook for documentation of field observations and measurements and a camera for taking photographs of clay exposures and other observed features that are relevant to the study.

From field observations, all locations within the study area consist of laterite except near Kutigi town, where two hills were observed to have deposits clay. Soil samples were collected from both hills, carefully labeled and points marked on the base map at the appropriate locations.

The hills were assigned location A and location $\mathrm{B}$ respectively for easy identification.

Thus, a total of twenty (20) clay samples weighing about $24 \mathrm{~kg}$, were randomly taken from both locations. All samples were carefully labeled and arranged in sac bags for the various analyses to be carried out in the laboratory.

\section{Laboratory Analysis}

A quantitative determination of the geotechnical properties of the clay samples was carried out at Civil Engineering Soil laboratory, Federal University of Technology Minna, Niger State Nigeria. The various analyses carried out include the determination of moisture content, Atterberg limit and particle size distribution. These laboratory analyses were carried out according to British Standard Methods of test for soils for civil engineering purposes. (BS 1377: part 2: 1990)

\section{Determination of the Coefficient of Permeability}

The value of the coefficient of permeability (k) varies widely for different soils. Some typical values of permeability coefficients are given in table.1.

Several empirical equations for estimation of the coefficient of permeability have been proposed in the past. For the purpose of this study only Hazen's proposed equation will be utilized.
For fairly uniform sand (that is, small uniformity coefficient), Hazen (1930) proposed an empirical relation for the coefficient of permeability in the form

$\mathrm{K}(\mathrm{cm} / \mathrm{sec})=\mathrm{cD}^{2}{ }_{10}$.

Where $\mathrm{c}=\mathrm{a}$ constant that varies from 1.0 to 1.5 .

$\mathrm{D}_{10}=$ the effective size, in millimeters.

The equation above is based primarily on observations made by Hazen on loose, clean filter sands. A small quantity of silts and clays, when present in a sandy soil, may change the coefficient of permeability substantially.

By taking $\mathrm{c}=1.3$ and estimating $\mathrm{D}_{10}$ values from the point of inflexion of the various grain-size curves, Hazen's empirical equation was used to estimate the coefficient of permeability and all results were accurately documented .

\section{Results and Discussion \\ Field observations.}

Two hills (location A and location B) were identified and observed to contain deposits of clay within the study area, both which are near, and separate by Kutigi town. Location A measures $\mathrm{N} 20^{\circ} \mathrm{W}$, while location $\mathrm{B}$ measures $\mathrm{N} 39^{\circ} \mathrm{E}$ of Egbako SW. Other location within the study area consists typically of laterite.

Result of geotechnical analysis of the clay samples.

\section{Moisture content and atterberg limit} results.

The results of the moisture contents and Atterberg limits of the geotechnical analysis of Kutigi clay deposits are presented in Table 2. The plasticity classification chart plotted for the clay sample is presented in Figure 2, while the modified plasticity classification chart plotted for the clay is presented in Figure 3. The moisture content results show that deposit of clay in location A have a higher moisture content value than those in location B. The moisture content of clays in location $\mathrm{A}$ is about $0.9 \%$, while that of location $\mathrm{B}$ is about $0.72 \%$. On the whole, the average moisture content of the soils yields very low result of about $0.81 \%$.

The Atterberg limit (which comprises the liquid limit (LL), plastic limit (PL), plasticity index (PI), and linear shrinkage limits (LSL)) results of the geotechnical analysis of the clay vary in values for both location A and location B when compared. For locations A and $\mathrm{B}$, the following physical parameters were 
observed respectively. An average; liquid limit of about $19.9 \%$ and $22.1 \%$, plastic limit of about $14.1 \%$ and $16.8 \%$, plasticity index of about $5.8 \%$ and $5.3 \%$, and a linear shrinkage limit of about $7.2 \%$ and $5.9 \%$.

A simple comparison of Atterberg limit results of location $\mathrm{A}$ to those of location $\mathrm{B}$, clearly show that location $\mathrm{A}$ have a lower liquid limit value with about $2.2 \%$, a lower plastic limit value with about $2.7 \%$, a higher plasticity index value with about $0.5 \%$ and a higher linear shrinkage limit value with about $1.3 \%$. On the whole, the results revealed a mean liquid limit of about $21 \%$, plastic limit of about $15.45 \%$, plasticity index of about $5.55 \%$ and a linear shrinkage limit of about $6.55 \%$ which are all below average.

The plasticity classification chart shows that the soils are composed of inorganic clay of low plasticity. The points that plot below the A- line constitute about 55\% and are classified as low silt-soils. Those which plot on the A-line constitute about $25 \%$ and are classified as low silty-clay soils, whilst those that plots above the A-line constitute about $20 \%$ of the total plots and are classified as low clay-soils. The plotted modified plasticity chart for classifying clay minerals suggests the presence of three clay minerals. They are montmorillonite, illite and kaolinite. Chlorite and halloysites are totally absent.The result indicated montmorillonite to constitute about $35 \%$ of the plots, illite constitute about $35 \%$ of the plots whereas kaolinite constitutes about $30 \%$.

\section{Sieve analysis results.}

The results of the sieve analysis of the clay deposits are summarized and presented in Table 3.

A simple comparison of results presented in Table 3 indicated that a mean result of about $95.85 \%$ grain-size passed through between test sieve-size $5 \mathrm{~mm}$ to $0.3 \mathrm{~mm}$ for location A, whilst those of location B recorded about $97.90 \%$ for the same range of sieves. Similarly, for test sieve-size ranging from $0.15 \mathrm{~mm}$ to $0.075 \mathrm{~mm}$, location A indicated a result of about $4.15 \%$ grain-size passing while location B indicated about $2.10 \%$ grain-size passing. These shows that soils from location A have more coarse grain-size particles for test sieve sizes $5 \mathrm{~mm}$ to $0.3 \mathrm{~mm}$ and more fine grainsize particles for test sieves $0.015 \mathrm{~mm}$ to $0.075 \mathrm{~mm}$. In addition, an average value of about $8.23 \%$ tended towards clay for location
A, as against a value of about $3.13 \%$, which tended towards clay for location B.

The results of the distributed particle sizes graded from fine sand to fine gravel, as observed from the plotted grain-size curves. These suggest the texture of the soil to be predominantly sandy.

A simple comparison of the curves shows that the coarser halves of the samples are relatively uniform, whereas the size of the grains in the finer halves varies over a wide range. These clearly classify the curves as those of immature residual soils. It is therefore hoped that with increasing age of the soil, the average grain-sizes will decrease due to weathering and the curves will become more nearly straight.

\section{Result of Estimated Coefficients of Permeability}

The results of the estimated coefficients of permeability of Kutigi clay using Hazen's proposed equation and their classifications according to soil types listed on Table 1 are summarized and presented in Table 4. The result of the estimated coefficients of permeability of the clay deposits indicated that clays in location A, are more coarse grained than those in location B. Practically, more coarse-grained soils have higher coefficients of permeability. Hence, location A has soils of higher coefficients of permeability than those of location B. On the average about $25 \%$ of the soils are classified as coarse sand while about $75 \%$ of the soils are classified as fine sand. These suggest the soils to be predominantly sandy.

\section{Discussion of Results}

The study area was mapped and it covers an area of about $39.88 \mathrm{~km}^{2}$. It is generally underlain by Enagi siltstone. During the mapping exercise two clay deposits were encountered, both of which are situated near and between Kutigi town. Location A, measures $\mathrm{N} 20^{\circ} \mathrm{W}$ of Egbako $\mathrm{SW}$ with an average height of about $38 \mathrm{~m}$ and a length of about $138 \mathrm{~m}$. While location B measures $\mathrm{N} 39^{\circ}$ E of Egbako SW, with a height of about $30 \mathrm{~m}$ and a length of about $110 \mathrm{~m}$. The deposits displayed a laterite - clay - sandstone lithological formation. The clay deposits are of varying thicknesses capped by thin lateritic soil. The clay varies from white to dirty white in colour and feels gritty to touch from hand specimen. Below the clay deposits lay deposits of sandstone. The area is also mark by a NW-SE and a NE-SE running ridges that are 
prominently composed of laterite. The ridges ranges from $15 \mathrm{~m}$ to $50 \mathrm{~m}$ in height as observed along the road cutting between Kutigi town and Ruga village.

Geotechnical investigation of the clay revealed a very low moisture content value of about $0.9 \%$ for location $\mathrm{A}$ and about $0.72 \%$ for location B. The Atterberg limit results of the soils suggest the following physical parameters respectively. An average; liquid limit of about $19.9 \%$ and $22.1 \%$, plastic limit of about $14.1 \%$ and $16.8 \%$, plasticity index of about $5.8 \%$ and $5.3 \%$, and a linear shrinkage limit of about $7.2 \%$ and $5.9 \%$.

On the whole the soils revealed a mean liquid limit of about $21 \%$, plastic limit of about $15.45 \%$, plasticity index of about $5.55 \%$ and linear shrinkage limit of about $6.55 \%$ which are all below average.

The plots on the plasticity classification chart revealed the soils to be composed of inorganic clay with low plasticity. The points that plot below the A- line constitute about 55\% and are classified as low silt-soils. Those which plot on the A-line constitute about $25 \%$ and are classified as low silty-clay soils. Whilst those which plots above the A-line constitute about $20 \%$ of the total plots and are classified as low clay-soils. Results from the modified plasticity classification chart revealed three clay minerals. These include montmorillonite (35\%), illite (35\%) and kaolinite (30\%).

Sieve analysis results revealed that within the coarser halves (i.e. test sieve-size ranging between $5 \mathrm{~mm}$ to $0.3 \mathrm{~mm}$ ), soils from location $\mathrm{A}$ are more coarse-grained than soils from location $\mathrm{B}$, and that, within the finer halves (i.e. test sieves size between $0.15 \mathrm{~mm}$ to $0.075 \mathrm{~mm}$ ), soils from location A are move finegrained than soils from location B.

Analysis of the grain-size curves revealed similar results, which suggest the soils to be predominantly sandy. The curves were also classified as those of immature residual soils as revealed from the typical grain-size curves.

Results of the estimated coefficients of permeability, from Hazen's proposed equation for fairly uniform sand, indicated soils from both locations to consist of high permeability values though soils from location $\mathrm{A}$, are more coarse-grained and have a higher coefficients of permeability than soils from location $B$. The results further revealed a higher porosity, lower tenacity, and a lesser degree of compactibility for soils in location A when compared to those of location B. A result of about $25 \%$ was classified as coarse-sand as against $75 \%$ that was classified as fine sand (see Tab. 4).

Geophysical investigation of Kutigi clay deposits of Alabi, (2005) revealed an area extent of about $57,400 \mathrm{~m}^{2}$ of clay bed in location A, and an area extent of $300 \mathrm{~m}^{2}$ in location B. He estimated the total reserve to about 672, 579 tons. Similarly, the chemical analysis of the clay deposits of Alabi, (2005) revealed a high dominance of $\mathrm{SiO}_{2} 66 \%, \mathrm{Al}_{2} \mathrm{O}_{3}$ $26.87 \%, \mathrm{TiO}_{2} 1.45 \%, \mathrm{Fe}_{2} \mathrm{O}_{3} 0.99 \%$, other elements ranged between $0.39 \%$ to trace. His estimated $\mathrm{SiO}_{2}$ value of about $66 \%$ closely agrees with the estimated percentage abundance of quartz of about $66.67 \%$ obtained from the mineralogical investigation carried out for the clays in course of this study.

\section{Conclusion}

On the basis of the results from the geological mapping, $\mathrm{x}$-ray diffraction analysis and geotechnical investigations, it can be deduced that the Kutigi clay occurred as immature, inorganic residual clay due to the weathering of feldspar from feldspathic sandstone, and it is predominantly kaolinitic in nature. The colour of the clay, which varies from white to dirty-white, is attributed to stains from the lateritic overburden. A low percentage value recorded for Kutigi kaolin (43.64\%) compared to higher percentage values recorded for some well- known kaolin deposit, in terms of their mineralogical composition are attributed to its high percentage of quartz.

More so, the grittiness of the clay, its low moisture contents, liquid limits, plastic limits, plasticity index, linear shrinkage limits and high permeability values are also attributed to the high dominance of quartz which makes both soils relatively pervious to the passage of water. These can also be easily observed from the grain size distribution curves, which grades from fine sand to fine gravel.

The results of the mineralogical and geotechnical investigation of the Kutigi clay deposits carried out in this study and the geochemical analysis of Alabi (2005); suggest that they can be utilized in the manufacture of ceramics, refractory bricks, paper, paint and fertilizers.

\section{Recommendations}

The geotechnical investigation of the Kutigi clay deposits was successfully carried out in this study. Again, the geology and 
mineralogy of the clay was carried out in a previous study while the geochemical and reserve estimation of the clay deposits have been carried out by Alabi, (2005). All that is most urgently needed is a further beneficiation of the clay deposits in order to ascertain the References.

Adegoke, O.S. (1979): Eocene Stratigraphy of Southern Nigeria. Mem. BRGMW 69 pp.23-49.

Adeleye, D.R. (1971): Stratigraphy and

Sedimentation of the Upper Cretaceous strata around Bida, Nigeria, Ph.D. Thesis University of Ibadan, Nigeria. pp297.

Adeleye, D.R., Dessauvagie, T.F.J. (1972):

Stratigraphy of the Niger Embayment near Bida, Nigeria. In Africa Geol. T.F.J. Dessauvagie and A.J. Whiteman (Eds). University of Ibadan Press, (1970), pp. 181-186.

Adeleye, D.R. (1973): Origin of ironstones, an example from the Middle Niger Valley, Nigeria, Jour. Sed. Petrol. 43, 709-727.

Adeleye, D.R. (1975). Nigeria late Cretaceou stratigraphy and Paleography. Bulletin of the American Association of Petroleum Geologist. 59, (12) 2302-2313 (5 figures)

Aderibigbe, D.A and Chukwuogo, C.E.B. (1984): Potential of Some Nigeria Clay Deposits as Refractory Materials for Steel Industry. Conf. Proc. Nig. Soc. of Engineers, Kano.

Alabi, A.A. (2005) Exploration and reserve estimation of clay-A case study of the Kutigi clay deposit of Bida Basin. Unpublished M. Tech. Thesis, Federal University of Technology Minna, Nigeria.

British Standard Institution Manual, (1990): Standard Methods of test for Soils for civil engineering purposes.BS 1377: part 2, pp.2-33.

Casagrande, A. (1932): Research on the Atterberg limits of soils. Public Road, New York, vol. 13 No.8. pp. 121-136. Coker, S.A., (1986): The Mineralogy and Geochemistry of Two Clay Deposits from Southeastern Nigeria. Unpub. M.Sc. Thesis, University of Ife, Nigeria.

Emofurieta, W.O. (1988): A comparative study of two kaolin deposits in South Western Nigeria. Jour. Min. and Geosc.24, pp 15-20.

Enu, E.I. and Adegoke, O.S. (1986): Industrial Potential of the Ifon Clay Belt, Southwest Nigeria. Journ. Geoscience vol II, No.1 pp2939. total ore grade and also exploit and identify the markets for the products. It is hoped that when these are done not only will the internal revenue of Niger State improve, but she will be able to provide jobs in the various local industries for her many unemployed citizens.

Faseke, O.O. (1981): Investigation of a clay deposit and the determination of its possible industrial utilization -A case study of the Ibule Clay Deposit. Unpub. M.Sc Thesis, Uni. of Ife, Nigeria.

Grim, R.E. (1968): The Clay Mineralogy $2^{\text {nd }}$ edition Mac Graw Hill, New York, pp. 596. Hazen, A. (1930). “Water Supply”, in American Civil Engineers Handbook Wiley, New York. Jan Du Chene, R.E., Onyike, M.S and Sowunmi M.A. (1978): Some new Eocene Pollen of the Ogwashi-Asaba formation, Southeastern Nigeria. Revista Espaniola de micropalaeontologia; 10, No.2, pp 258-322. Kogbe, C.A. (1981): Geological interpretation of Landsat imageries of part of Nigeria. Journal of Mining and Geology. 18, pp.66-69.

Lambe, T.W. (1951): Soil testing for engineers, New York, John Wiley and Sons, pp165.

McGeary P. (1998): Physical Geology third edition. Pg. 208.

Proceng Consultants Report (1974): The refining of Kaolin in the Western State- A feasibility study. An Unpub.Consultancy Report Western State Ministry of Industries, Ibadan.

Read, H.H. (1970): Rutleys element of mineralogy, George Allen (publisher) Ltd printed in Great Britain. pp. 164-177. United State Bureau of Reclamation, (1963). Earth Manual, 1st ed. Revised, Wash. D.C., pp.783.

Velde, B. (1995): Composition and mineralogy of clay minerals, in Velde, B., Ed., Origin and Mineralogy of clays: New York, Springerverlag, pp. 8-42.

Waudby-Smith, J.E. (1957): A summary of the principal known deposits of clay in Nigeria. An unpubl. Geol. Survey of Nigeria Report No. 1395.

Whiteman, A. (1982): Nigeria, its Petroleum Geology, Resources and Potential. vols.1 and 2. Graham and Trotman, London, 394p. 
Table 1: Typical Values of Permeability Coefficients (after Hazen, 1930)

\begin{tabular}{|l|l|l|}
\hline \multirow{2}{*}{ Soil type } & $\mathbf{K}$ & \multicolumn{2}{|c|}{$(\mathbf{F t} / \mathbf{m i n})$} \\
\cline { 2 - 3 } & $(\mathbf{C m} / \mathbf{s e c})$ & $2.0-200$ \\
Clean gravel & $1.0-100$ & $2.0-0.02$ \\
Coarse sand & $1.0-0.01$ & $0.01-0.002$ \\
Fine sand & $0.01-0.001$ & $0.002-0.00002$ \\
Silty & $0.001-0.00001$ & Less than 0.000002 \\
Clay & Less than 0.000001 & \\
\hline
\end{tabular}

Table 2: Summary of results from laboratory analysis for Kutigi Clay

\begin{tabular}{|c|c|c|c|c|c|}
\hline \multirow[b]{2}{*}{ Sample No. } & \multirow{2}{*}{$\begin{array}{l}\text { Moisture } \\
\text { content } \\
\text { (\%) }\end{array}$} & \multicolumn{4}{|c|}{ Atterberg limit } \\
\hline & & $\begin{array}{l}\mathbf{L L} \\
(\%)\end{array}$ & $\begin{array}{l}\text { PL } \\
(\%)\end{array}$ & $\begin{array}{l}\text { PI } \\
(\%)\end{array}$ & $\begin{array}{l}\text { Linear } \\
\text { shrinkage } \\
\text { limit (LSL) } \\
(\%)\end{array}$ \\
\hline $\operatorname{LocA}_{1} / 1$ & 1.4 & 15 & 9 & 6 & 11 \\
\hline $\operatorname{LocA}_{1} / 2$ & 0.51 & 16 & 10 & 6 & 7 \\
\hline $\operatorname{LocA}_{2} / 3$ & 1.1 & 29 & 21 & 8 & 2 \\
\hline $\mathrm{LocA}_{2} / 4$ & 0.22 & 20 & 16 & 4 & 8 \\
\hline $\mathrm{LocA}_{3} / 5$ & 1.31 & 30 & 26 & 4 & 11 \\
\hline $\mathrm{LocA}_{3} / 6$ & 0.94 & 21 & 15 & 6 & 3 \\
\hline $\mathrm{LocA}_{4} / 7$ & 0.75 & 17 & 9 & 8 & 6 \\
\hline $\mathrm{LocA}_{4} / 8$ & 0.73 & 10 & 7 & 3 & 9 \\
\hline $\operatorname{LocA}_{5} / 9$ & 0.76 & 19 & 9 & 10 & 6 \\
\hline $\mathrm{Loc}_{5} / 10$ & 1.32 & 22 & 19 & 3 & 9 \\
\hline Arithmetic Mean & 0.9 & 19.9 & 14.1 & 5.8 & 7.2 \\
\hline Range $\longrightarrow$ & $\begin{array}{l}0.22 \text { to } \\
1.4\end{array}$ & $\begin{array}{l}10 \\
\text { to } \\
30\end{array}$ & $\begin{array}{l}7 \text { to } \\
26\end{array}$ & $\begin{array}{l}3 \text { to } \\
10\end{array}$ & 2 to 11 \\
\hline $\operatorname{LocB}_{1} / 11$ & 0.37 & 19 & 15 & 4 & 6 \\
\hline $\operatorname{LocB}_{1} / 12$ & 0.52 & 23 & 20 & 3 & 16 \\
\hline $\operatorname{LocB}_{1} / 13$ & 0.58 & 23 & 17 & 6 & 9 \\
\hline $\mathrm{LocB}_{1} / 14$ & 0.57 & 22 & 18 & 4 & 4 \\
\hline $\operatorname{LocB}_{1} / 15$ & 0.56 & 21 & 15 & 6 & 2 \\
\hline $\mathrm{LocB}_{2} / 16$ & 0.72 & 21 & 17 & 4 & 4 \\
\hline $\operatorname{LocB}_{2} / 17$ & 0.99 & 35 & 25 & 10 & 1 \\
\hline $\operatorname{LocB}_{2} / 18$ & 0.88 & 17 & 13 & 4 & 3 \\
\hline $\mathrm{LocB}_{2} / 19$ & 0.9 & 20 & 16 & 4 & 6 \\
\hline $\operatorname{LocB}_{2} / 20$ & 1.08 & 20 & 12 & 8 & 8 \\
\hline Arithmetic Mean $\longrightarrow$ & 0.72 & 22.1 & 16.8 & 5.3 & 5.9 \\
\hline${ }^{`}$ Range $\longrightarrow$ & $\begin{array}{l}0.37 \text { to } \\
1.08\end{array}$ & $\begin{array}{l}17 \\
\text { to } \\
35\end{array}$ & $\begin{array}{l}12 \\
\text { to } \\
25\end{array}$ & $\begin{array}{l}3 \text { to } \\
10\end{array}$ & 1 to 16 \\
\hline
\end{tabular}

$\mathrm{LL}=$ Liquid Limit

$\mathrm{PL}=$ Plastic Limit

PI = Plasticity Index 


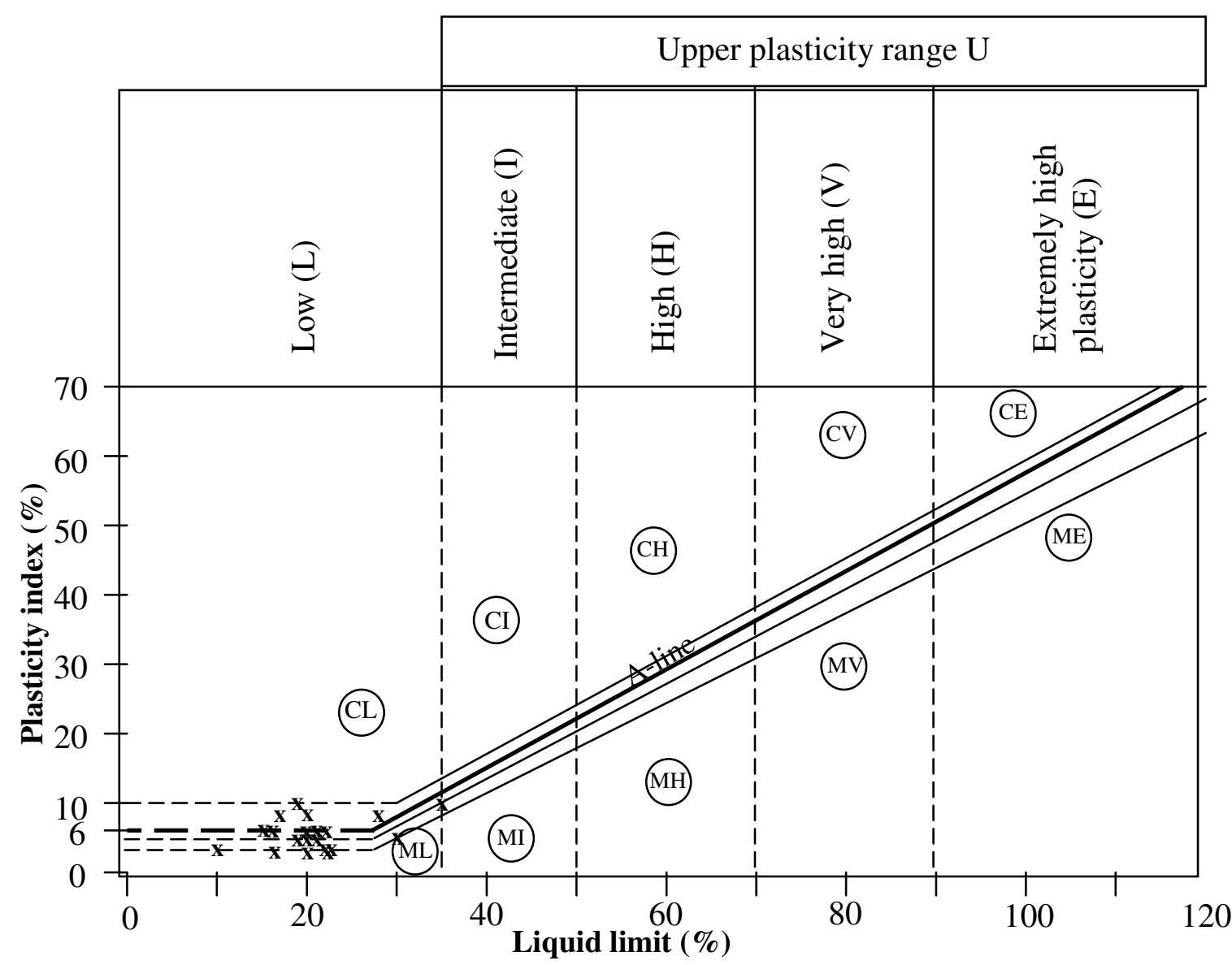

Notes: 1. Silt (M-soil), plots below A -line Clay (C-soil), plots above A-line $\mathrm{M}$ and $\mathrm{C}$ may be combined as fine soil $\mathrm{F}$

2. the letter ' $\mathrm{O}$ ' is added to the symbol of any material containing a significant proportion of organic matter (e.g. MHO)

3. chart is based on material passing a $425 \mu \mathrm{m}$ BS sieve.

Fig. 2: Plasticity classification chart plotted for Kutigi clay (after A. Casagrande (1932)).

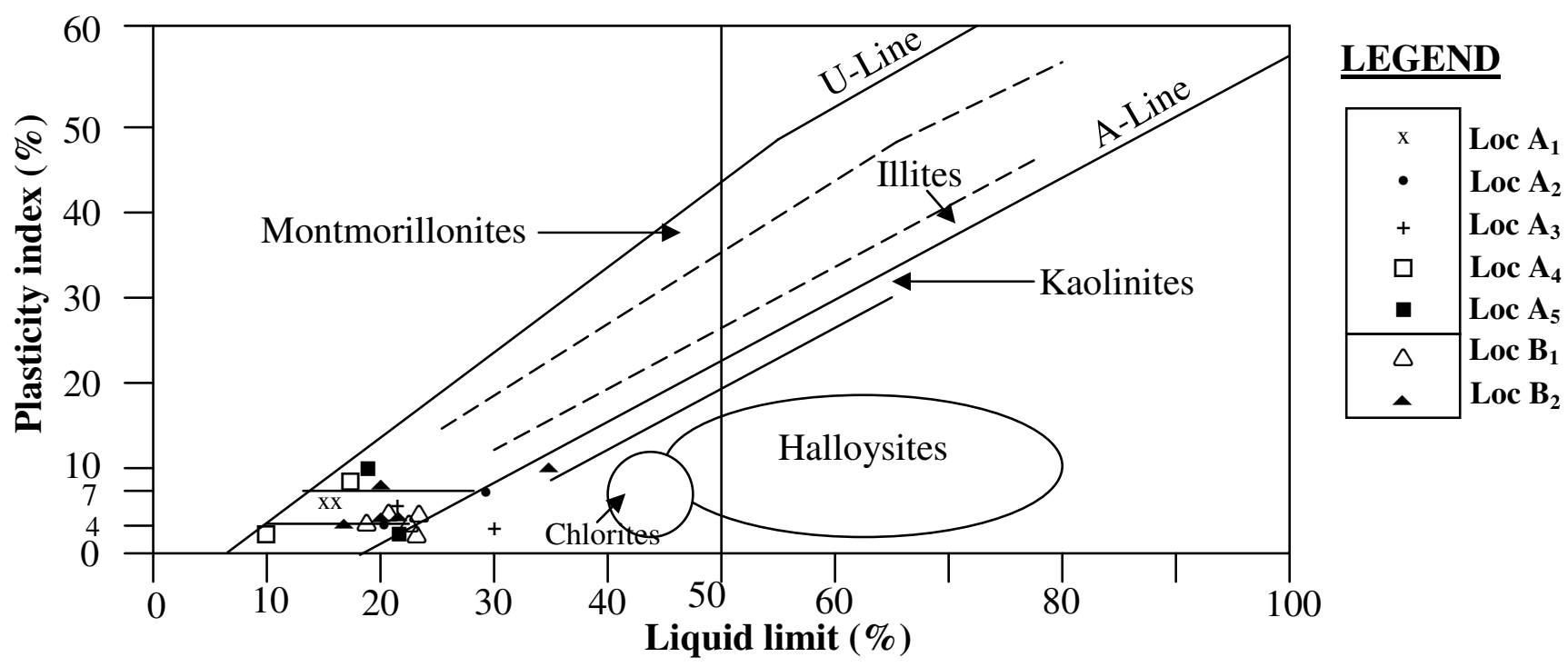

Fig.3: Modified plasticity classification chart plotted for Kutigi clay (after USBR 1963) 
Table 3: Results of Sieve Analysis of Kutigi clay

\begin{tabular}{|c|c|c|c|c|c|c|c|c|c|c|c|}
\hline \multirow{2}{*}{$\begin{array}{l}\text { Sample } \\
\text { No. }\end{array}$} & \multirow{2}{*}{$\begin{array}{l}\text { Sieve } \\
\text { Size } \\
(\mathrm{mm})\end{array}$} & \multicolumn{10}{|c|}{ Sieve Analysis (\% passing) } \\
\hline & & 5 & 3.35 & 2 & 1.18 & 0.85 & 0.6 & 0.425 & 0.3 & 0.15 & 0.075 \\
\hline $\operatorname{LocA}_{1} / 1$ & & 96.54 & 89.29 & 74.63 & 49.92 & 42.01 & 34.93 & 28.5 & 22.57 & 6.42 & 3.78 \\
\hline $\operatorname{LocA}_{1} / 2$ & & 96.82 & 87.74 & 74.05 & 49.69 & 41.57 & 34.25 & 26.77 & 20.56 & 4.8 & 2.25 \\
\hline $\operatorname{LocA}_{2} / 3$ & & 98.36 & 93.44 & 88.52 & 75.41 & 67.21 & 57.37 & 44.26 & 39.34 & 26.23 & 24.59 \\
\hline $\mathrm{LocA}_{2} / 4$ & & 100 & 100 & 100 & 81.95 & 70.84 & 58.34 & 50.01 & 44.45 & 31.95 & 16.67 \\
\hline $\mathrm{LocA}_{3} / 5$ & & 100 & 100 & 100 & 98.37 & 97.28 & 95.65 & 93.48 & 87.5 & 17.93 & 8.69 \\
\hline $\mathrm{LocA}_{3} / 6$ & & 100 & 100 & 100 & 97.3 & 91.89 & 89.19 & 35.14 & 18.92 & 16.22 & 2.71 \\
\hline $\mathrm{LocA}_{4} / 7$ & & 84.62 & 76.93 & 76.93 & 73.08 & 69.23 & 69.23 & 46.15 & 26.92 & 23.07 & 7.69 \\
\hline $\mathrm{LocA}_{4} / 8$ & & 94.12 & 94.12 & 76.47 & 76.47 & 64.71 & 58.83 & 41.18 & 29.42 & 11.77 & 5.89 \\
\hline $\operatorname{LocA}_{5} / 9$ & & 100 & 100 & 100 & 98.34 & 95.44 & 94.2 & 92.96 & 88.81 & 21.18 & 6.66 \\
\hline $\begin{array}{l}\operatorname{LocA}_{5} / 1 \\
0\end{array}$ & & 100 & 100 & 97.39 & 96.27 & 94.78 & 92.54 & 88.81 & 80.97 & 18.66 & 3.36 \\
\hline \multicolumn{2}{|c|}{ Arithmetic Mean $\rightarrow$} & 97.05 & 94.15 & 88.8 & 79.68 & 73.5 & 68.45 & 54.73 & 45.95 & 17.82 & 8.23 \\
\hline \multicolumn{2}{|c|}{ Range $\longrightarrow$} & $\begin{array}{l}84.62 \\
\text { to } \\
100\end{array}$ & $\begin{array}{l}76.93 \\
\text { to } \\
100\end{array}$ & $\begin{array}{l}74.05 \\
\text { to } \\
100\end{array}$ & $\begin{array}{l}49.69 \\
\text { to } \\
98.37\end{array}$ & $\begin{array}{l}41.57 \\
\text { to } \\
97.28\end{array}$ & $\begin{array}{l}34.25 \\
\text { to } \\
95.65\end{array}$ & $\begin{array}{l}26.77 \text { to } \\
93.48\end{array}$ & $\begin{array}{l}18.92 \\
\text { to } \\
88.81\end{array}$ & $\begin{array}{l}4.8 \text { to } \\
31.95\end{array}$ & $\begin{array}{l}2.55 \\
\text { to } \\
24.59\end{array}$ \\
\hline $\operatorname{LocB}_{1} / 11$ & & 100 & 99.09 & 98.33 & 97.57 & 96.5 & 93.91 & 89.34 & 80.21 & 8.98 & 2.13 \\
\hline $\operatorname{LocB}_{1} / 12$ & & 96.9 & 83.3 & 58.52 & 42.34 & 35.63 & 29.78 & 24.27 & 19.62 & 4.99 & 2.75 \\
\hline $\operatorname{LocB}_{1} / 13$ & & 100 & 100 & 98.59 & 96.13 & 92.79 & 88.92 & 82.59 & 77.14 & 7.19 & 2.62 \\
\hline $\operatorname{LocB}_{1} / 14$ & & 98.11 & 87.73 & 66.82 & 51.73 & 45.91 & 35.69 & 29.72 & 22.33 & 6.76 & 2.83 \\
\hline $\operatorname{LocB}_{1} / 15$ & & 96.98 & 82.41 & 56.95 & 41.37 & 34.67 & 28.64 & 23.45 & 18.76 & 4.19 & 2.18 \\
\hline $\begin{array}{l}\text { LocB2/1 } \\
6\end{array}$ & & 100 & 100 & 100 & 99.13 & 97.61 & 96.52 & 93.69 & 87.82 & 13.04 & 3.04 \\
\hline $\begin{array}{l}\text { LocB2/1 } \\
7\end{array}$ & & 100 & 100 & 99.78 & 98.88 & 98.21 & 76.86 & 94.48 & 89.23 & 16.81 & 4.48 \\
\hline $\begin{array}{l}\text { LocB2/1 } \\
8\end{array}$ & & 100 & 100 & 100 & 98.76 & 97.1 & 84.2 & 90.27 & 83.02 & 14.9 & 3.51 \\
\hline $\begin{array}{l}\text { LocB2/1 } \\
9\end{array}$ & & 100 & 100 & 99.54 & 99.31 & 98.4 & 96.81 & 94.99 & 89.07 & 14.58 & 4.1 \\
\hline $\begin{array}{l}\text { LocB2/2 } \\
0\end{array}$ & & 100 & 100 & 100 & 98.5 & 96.57 & 93.14 & 89.28 & 80.7 & 17.18 & 3.66 \\
\hline \multicolumn{2}{|c|}{ Arithmetic Mean $\longrightarrow$} & 99.2 & 95.25 & 87.85 & 82.37 & $\begin{array}{l}79.34 \\
\end{array}$ & 72.45 & 71.21 & 64.79 & 10.86 & 3.13 \\
\hline Range & $\longrightarrow$ & $\begin{array}{l}96.9 \\
\text { to } \\
100\end{array}$ & $\begin{array}{l}82.41 \\
\text { to } \\
100\end{array}$ & $\begin{array}{l}56.95 \\
\text { to } \\
100\end{array}$ & $\begin{array}{l}41.37 \\
\text { to } \\
99.31\end{array}$ & $\begin{array}{l}34.67 \\
\text { to } 98.4\end{array}$ & $\begin{array}{l}28.64 \\
\text { to } \\
96.81\end{array}$ & $\begin{array}{l}23.45 \text { to } \\
94.99\end{array}$ & $\begin{array}{l}18.76 \\
\text { to } \\
89.23\end{array}$ & $\begin{array}{l}4.19 \text { to } \\
17.18\end{array}$ & $\begin{array}{l}2.13 \\
\text { to } \\
4.48\end{array}$ \\
\hline
\end{tabular}


Table 4: Classification of result of estimated coefficient of permeability for Kutigi clay.

\begin{tabular}{|l|l|l|l|l|}
\hline Sample No. & $\begin{array}{l}\text { Effective } \\
\text { Size D10 } \\
(\mathrm{Mm})\end{array}$ & $\begin{array}{l}\text { Effective } \\
\text { Size D10 } \\
(\mathrm{Cm})\end{array}$ & $\begin{array}{l}\text { K } \\
(\mathrm{Cm} / \mathrm{Sec}) \\
=\mathrm{Cd} 210\end{array}$ & Soil Type \\
\hline LocA1/1 & 1.18 & 0.118 & 0.018 & Coarse sand \\
\hline LocA1/2 & 1.5 & 0.15 & 0.029 & Coarse sand \\
\hline LocA2/3 & 0.85 & 0.085 & 0.009 & Fine sand \\
\hline LocA2/4 & 0.425 & 0.0425 & 0.002 & Fine sand \\
\hline LocA3/5 & 0.2 & 0.02 & 0.001 & Fine sand \\
\hline LocA3/6 & 0.425 & 0.0425 & 0.002 & Fine sand \\
\hline LocA4/7 & 0.5 & 0.05 & 0.325 & Coarse sand \\
\hline LocA4/8 & 0.5 & 0.05 & 0.325 & Fine sand \\
\hline LocA5/9 & 0.212 & 0.0212 & 0.001 & Fine sand \\
\hline LocA5/10 & 0.25 & 0.025 & 0.001 & Fine sand \\
\hline LocB1/11 & 0.27 & 0.027 & 0.001 & Fine sand \\
\hline LocB1/12 & 1.60 & 0.16 & 0.033 & Fine sand \\
\hline LocB1/13 & 0.3 & 0.03 & 0.001 & Fine sand \\
\hline LocB1/14 & 1.18 & 0.118 & 0.018 & Coarse sand \\
\hline LocB1/15 & 1.5 & 0.15 & 0.029 & Coarse sand \\
\hline LocB2/16 & 0.27 & 0.027 & 0.001 & Fine sand \\
\hline LocB2/17 & 0.25 & 0.025 & 0.001 & Fine sand \\
\hline LocB2/18 & 0.3 & 0.03 & 0.001 & Fine sand \\
\hline LocB2/19 & 0.3 & 0.03 & 0.001 & Fine sand \\
\hline LocB2/20 & 0.212 & 0.0212 & 0.001 & Fine sand \\
\hline
\end{tabular}

Note: $c=1.3$ 